\title{
Factors Affecting Quality of Life Among Independent Community-Dwelling Senior Citizens in Sri Lanka: A Narrative Study
}

\author{
Machiko Higuchi $^{1} \&$ Chandani Liyanage ${ }^{2}$ \\ ${ }^{1}$ National College of Nursing, Japan, National Center of Global and Medicine, Tokyo, Japan \\ ${ }^{2}$ Department of Sociology, University of Colombo, Colombo, Sri Lanka \\ Correspondence: Machiko Higuchi, National College of Nursing, Japan, Professor, 1-2-1 Umezono Kiyose \\ Tokyo Japan.
}

Received: February 7, 2019

Accepted: March 5, 2019

Online Published: March 12, 2019

doi:10.20849/ajsss.v4i1.554

URL: https://doi.org/10.20849/ajsss.v4i1.554

\begin{abstract}
Objectives: This study aimed at gaining an understanding of senior citizens' lifestyles from childhood and clarifying the factors important in sustaining their quality of life (QOL).

Methods: Using purposive sampling, in-depth interviews by semi-structured interview guide were conducted among five senior citizens in a Sri Lankan community. The interviews were analysed narratively.

Results: Three males and two females over the age of 70 were interviewed. All had obtained a decent level of education and lived with extended family. They had sound relationships with their children and were engaged in social roles, keeping them occupied and giving their lives a sense of meaning. They made use of both Western and traditional medicine, including religious activities, depending on their ailments.

Conclusion and further research: The QOL of independent community-dwelling senior citizens in Sri Lanka was related to education, psychological independence, sustaining daily life, engagement in social activities, and satisfaction with children's support, house sitting for their children, and engaging in multiple health activities to prevent and treat symptoms. Further narrative research is suggested to highlight the individual experiences of senior citizens, which will help develop an effective strategy for sustaining the QOL of this population in Sri Lanka.
\end{abstract}

Keywords: independent senior citizen, community based study, quality of life, narrative study, Sri Lanka

\section{Introduction}

Every country in the world is experiencing growth in the number and proportion of senior citizens in the population. The pace of population ageing in many developing countries is substantially faster than experienced by developed countries in the past. Consequently, today's developing countries must adapt much more quickly to ageing populations and often at much lower levels of national income as compared to the experience of countries that developed much earlier (UN, 2015). Preparing for the economic and social shifts associated with an ageing population is thus essential to ensure progress in development, including towards the achievement of the goals outlined in the 2030 Agenda for Sustainable Development (UN, 2015).

Ageing is a series of processes that begins with life and continues throughout the life cycle. As life leads towards death, each moment from birth influences the quality of life (QOL), including quality of death. However, discussions on end-of-life care get pushed under the rug for as long as possible, sometimes for so long that it is too late to take meaningful steps to ease the transition.

Sri Lanka is one of the faster-ageing countries in the world. The percentage of those over 60 years of age was estimated to be $12.3 \%$ in 2012, as opposed to $9.2 \%$ in 2001 (Ministry of Health, Nutrition and Indigenous Medicine, 2014). This figure will reach over 20\% in 2050 (UN, 2015). Despite low expenditure on healthcare, Sri Lanka's health indicators are similar to more developed countries in the region (The Economist, 2014). In Sri Lanka, from 2000 ( 71.5 years) to 2016 (74.9 years), the life expectancy at birth has improved by 3.4 years while from 2000 (63.9 years) to 2016 (67.0 years), healthy life expectancy has improved by 3.1 years (SEARO, 2018). Analysis of age-standardised data for 2015 shows that chronic non-communicable disease (NCD) mortality in Sri Lanka is higher than that of many developed countries. Thus, NCDs account for $83 \%$ of all deaths in Sri 
Lanka (WHO, 2018). Disease patterns in Sri Lanka have been changing over the past few decades. This has been in tandem with a demographic and epidemiological transition where NCDs are becoming a threat to human development. The World Health Organization defines QOL as 'individuals' perception of their position in life in the context of the culture and value systems in which they live and in relation to their goals'. Risky individual lifestyles developed during childhood have become one of the main causes of NCDs (Muenning, et al., 2011; Knudsen, Heckman, Cameron, \& Shonkoff, 2006, Conti, Heckman \& Pinto, 2016; Miller, G., Vael, Aimee. C., Hires, K. A., \& Eades, L. H. 2018). Therefore, effective early educational programmes may improve health and reduce risky health behaviours in adulthood (Muenning et al., 2011).

Accordingly, it is very important to understand senior citizens' lifestyles from childhood. However, data on the life history of senior citizens in Sri Lanka is not available. Therefore, this study involved observation and interviews of senior citizens leading independent lives to clarify the factors necessary in sustaining their QOL.

\section{Method}

\subsection{Research Design}

A descriptive approach using semi-structured interviews to reveal independent community-dwelling senior citizens' life histories was employed.

We conducted in-depth interviews using an interview guide developed by the authors to collect data from five senior citizens over 70 years who were managing their daily lives independently in the Western province of Sri Lanka. We analysed the data narratively.

\subsection{Ethical Considerations}

Information regarding the primary aim of the study and voluntary nature of participation was provided before conducting the interviews. Ethical clearance was obtained from the Ethics Review Committee of the institution to which one of the authors belongs.

\section{Results}

\subsection{Basic Attributes of Respondents}

Three male and two female senior citizens, all of whom are Buddhists living in their native village, were interviewed. Three are in their $70 \mathrm{~s}$, one is in the $80 \mathrm{~s}$, and one is 90 years old. The 78 -year-old male runs a grocery shop. One 75-year-old female used to be a tailor. The 90 -year-old male, who used to work as a bus conductor, is one of members of the community-based organisations. All respondents have completed more than nine years of education. Two out of five had arranged marriages, while the remaining married for love with the acceptance of their parents. All of them had simple yet meaningful wedding parties, lead simple lives and appreciate what they have, and emphasise that the happiest moments of their lives are related to health and family.

\subsection{Family Background}

The fathers of all respondents had been farmers, while their mothers had sold their products at the market. All respondents lived with extended family. After marriage, they had continued to live with their parents in the same premises. Person 3 (P3) stated: My father was a betel farmer, which fetched him a high income. I engaged in betel farming for a few years. My mother went to a market $6 \mathrm{~km}$ from home to sell the betel. I accompanied her on these trips. At the time, it was said that it is good to engage in both wet rice farming and dry farming. She took betel leaves and vegetables like sponge gourd, ladies' fingers, snake gourd, and chilies to sell at the market. P4 stated: My parents were farmers. My mother used to take vegetables from our own land and bought vegetables from other farmers to sell at the market.

After the respondents' children were married, they left home and lived near the village. All respondents' children visit them often with meals and other daily necessities. P3 stated: I have nine brothers and sisters and only a younger sister and myself alive. My parents brought us up well. My children and grandchildren visit us every day. They bring food and drink and ask about my health and daily necessities. They look after us well. P4 described: I have four children. My younger daughter is a pre-school teacher. My elder son runs a small garment factory while the younger one runs a car cleaning centre. When my husband died because of cerebral infarction, my younger daughter came to live with me. The other three children live nearby. They visit me regularly and treat me well. If my younger son gets married and comes to live here, my younger daughter will go back to her home. 


\subsection{Life in Childhood}

\subsubsection{Schooling}

All respondents had obtained more than nine years of public education, which was higher than the average in 1950's Apart from the regular subjects, their public school also involved a practical aspect, and they learned how to cultivate. They walked a few miles to school daily. P1 stated: I walked to school, which was $3.5 \mathrm{~km}$ from home. I learnt Sinhala, agriculture, Buddhism, geography, history, and so on. We were taught six subjects. We learnt how to cultivate many kinds of plants, such as chilies, snake gourd, beans, ladies' fingers, and sponge gourd, which were then sent to be sold at fairs. The income was distributed among students and teachers.

\subsubsection{Activities out of School}

During their school days, all of them assisted their parents with their work, whether it was harrowing and ploughing or looking after cows. One hour after returning from school was reserved for playing with friends. They participated in religious activities on weekends to sustain the traditions of the village's Buddhist temple. In P1's words: After I came back home from school, we spent most of the time playing games, though our father punished us when these involved running and jumping. I helped father harrow and plough depending on the season. We helped father on the field on the holidays, which required physical engagement. P3 stated: Every morning, I took 30 cows to the estate $1 \mathrm{~km}$ away and brought them back in the evening. When I did not have to bring the cows back, I spent an hour playing with friends. I spent an hour at the temple on Sunday mornings and every evening during the week to offer flowers and meditate. In case the monks had not received any alms, we prepared and offered food. So, we had a close relationship with the temple. I built the platform where the preacher can deliver sermons. Then, when I was around 60 years old, the chief incumbent of the temple began visiting me.

\subsubsection{Eating Habits}

The participants ate simple, healthy meals prepared from local products. The previous night's leftover rice, mixed with coconut milk, green chili and red-onion, jackfruit, and a variety of vegetables and fruits they had themselves cultivated or which grew in their gardens, constituted breakfast. They seldom ate readymade store-bought food. P1 stated: We often ate the rice remaining after the previous night's dinner cooked one, curd, and jackfruit. We ate homemade curd with all three meals. We ate parboiled rice, that is, sudu kekulu, rathu kekulu, and nadu haal with fish or meat every day with vegetables like sponge gourd, snake gourd, ladies' fingers, and eggplant, which were grown by the family. My mother went to the market every Saturday and brought back either hoppers or buns. Other than this, we did not eat readymade foods. P3 stated: We ate the rice remaining from the previous night cooked one with coconut sambol and coconut milk gravy as breakfast and rice with sponge gourd, snake gourd, potato, sweet potato, cassava, jackfruit, breadfruit, and mallung for lunch and dinner. We planted most vegetables in our own garden. P4 described: We often ate gram, that is, green gram, black gram, horse gram and cowpea. We got several kinds of wild meat, for example rabbit, stag, and deer meat, brought by my brothers. My mother brought chicken, beef, and pork from the market. When our cultivated rice was not enough, we also bought rice from the market. We ate fish such as seer fish, ray, and shark; vegetables such as cassava, potato, sweet potato, jackfruit, snake gourd, sponge gourd, kankun, mukunuwenna, and gotukola; and fruits such as pomegranate, orange, banana, pineapple, papaya, and guava from our garden. We ate only natural ripened fruits. P5 stated: Sometimes, mother prepared string hoppers or brought hoppers from shops. We ate meat or fish twice a week when my parents brought them from the market; otherwise, we usually ate rice, vegetables, and dry fish. As we did not have a refrigerator to store food, we finished whatever was prepared on the same day. Sometimes, my mother prepared lunudehi and achcharu.

\subsection{Traditional Activities}

\subsubsection{Health Behaviour}

They practised traditional health behaviours, which included the consumption of herbal drinks and foods to prevent and cure ailments. To prevent any symptoms from worsening, they reduced their food intake. They took a bath at a particular time. When they experienced common symptoms, they consulted traditional doctors and recited a particular verse meant for incurable illnesses. P1 mentioned: In the past, when we got fever, we were not allowed to have meals. We had lunu kenda, sago kenda, and gotukola kenda. We used to consult a skillful traditional doctor in the village, who could make a diagnosis just by checking the pulse. If the symptoms did not improve after his treatment, we went to a hospital of Western medicine. This happened once or twice a year. In case of serious conditions like blisters on the skin, the patient took a steam bath in a place covered from coconut leaves at the backside of house, and we sang verse for good luck and health. P2 stated: When we became ill, we 
reduced our food intake. People thought their fever would worsen if they ate. We were made to drink koththamalli, coriander water, or lunu kenda. P3 described: We drank tea and herbal porridge made from gotukola, tora and mukunuwenna kola. I used to go to the mountain to take leaves with my sisters those days. We still drink herbal porridge. We buy leaves from the market. When we became ill, we had only lunu kenda to drink and hulan iskothu (one kind of biscuit) to eat. We were also made to drink a combination of soda, ginger, and coriander water. In case of illness, we were not allowed to drink king coconut water. P4 described: When we got chickenpox, my parents fed us only vegetables; no meat or fish. In addition, we were given oranges, sugarcane, and pomegranate. However, we could only eat these fruits after we took a bath until recovering from the illness. When we had chickenpox, we did not take a bath. Twenty-one days after recovering from chickenpox, we took a bath. We were often given porridge during these 21 days. As we had our own well, we went to take a bath around 3:30 am or 4:00 am. If people had happened to see us at that time, they might have been frightened by our appearance. As there was no one around so early in the morning, we could bathe freely.

\subsubsection{Pregnancy and Childbearing}

Two female respondents and the wives of three male respondents engaged in traditional health activities such as consuming particular foods and taking a bath at a specific time during childbearing. In the case of minor symptoms, babies were given herbal medicines. P2 (female) stated: When I became pregnant, I went to a traditional healer. He touched my hand and checked my pulse. This was how he estimated the date and time of delivery. I delivered the baby at the exact time and date he mentioned. I avoided eating a certain kind of food called ushna kaama such as pineapples. I tried a lot of young jackfruit curry and young jackfruit's mallung. I gave my baby kenda and boiled potatoes as a weaning food. In the case of a minor illness such as a cold or cough, we gave the baby home remedies such as boiled coriander water. The infant was bathed at around 10:30 am or 11:00 am because infants feel cold if bathed in the afternoon. P4 (female) mentioned: During pregnancy, I did not eat ushna kaama such as pineapple, taro, and breadfruit. I vowed to the goddess pattini. I drank the beverage of the king coconut after charming the angulimala pirith. Before we went to the hospital for the delivery, we performed a bodhi pooja. There were restrictions on what I could eat until three days after the delivery at the hospital. I ate thambun hodi and rice. I was not allowed to eat these foods after the delivery because people believe that consuming dead animals is not good for the stomach immediately after delivery. When our parents prepared food during those days, they did not add even red onion to curries. They added only garlic. Red onion is an ushna kaama and it has an unpleasant smell. A few days after the delivery, we started eating normal food. We ate shark as this fish is considered good for the production of breast milk. We ate tuna and the shell of dried fish. Tuna is considered good for blood production. In addition, we ate young jackfruit for the production of breast milk. Dried fish shells were chopped and added to the curry. We ate these foods for all three meals. Polpala kola, which is considered a siitala kaama, was not to be eaten until three months after delivery. People believed that if eaten soon after delivery, polpala kola would get attached to the intestines. P5 stated: When my wife became pregnant, we performed a bodhi pooja. When a child was born, we did the custom of idul kata gema.

\subsection{Religious Activities for Health Problems}

They engaged in various religious activities not only to control health problems but also to prevent babies from getting diseases. P2 stated: In the past, people had died because of ageing or snake bites. People also got illnesses such as fever, chickenpox and diarrhea. When a family member became ill, we engaged in religious activities such a bodhi pooja and made vows. We especially vowed to the kiri amma. We organised gammudawa to control diseases. The elders were at the helm of the religious activities.

Other than those who had died of cholera, most deaths were due to ageing. Measles and chickenpox were communicable diseases. P3 stated: Villagers organised the gammudawa, where people did kappa hitaveema. In kappa hitaveema, there is a pole placed in the ground, around which are tied coconut tree's flowers. After that, a kappa mahatmayaa comes and starts incantation. We had to invite an exorcist from another village as ours did not have one (No.3). Most people in the past died due to ageing. Fever, chickenpox, and measles were common diseases. People organised gammudawa and gihipirith. When family members suffered from illnesses such as measles and chickenpox, we vowed to the goddess pattini and a Buddhist monk gave blessings by chanting pirith to protect the village.

\subsection{Current Health Behaviours}

All of them lead regular lives, waking up early and eating at the same time every day. Some take a bath at a particular time according to the theory of traditional medicine. They are engaged in some work. None of them watches television. They listen to the Buddhist religious programme on the radio and read the newspapers. None 
of them smokes, and some occasionally consume local alcohol. P1 stated: I get up at 5:30 am. I boil water and wake my wife up. After that, I drink a cup of tea and get ready to go to town by bicycle. I go to town at 6:15 am and at $3: 30 \mathrm{pm}$ and come back after one hour. I eat bread and some other food from hotels for breakfast as it is now difficult for my wife to wake up and cook in the morning. My daughters bring home-cooked meals. I eat vegetable and meat curries for lunch and dinner. I spend my time reading the novels and short stories my son and grandchildren bring. I go to bed around $11 \mathrm{pm}$ or $12 \mathrm{pm}$. I drink boiled warm water, which is good for health. P2 stated: I get up between 7:00 am and 7:30 am as I have back pain, painful joints, and rheumatism. I take breakfast around 8:00 am or 8:30 am, lunch around 1:00 pm, and dinner around 8:00 pm. I take a bath whenever I am free. P5 described: I get up by 4:30am. I wash my face, drink a cup of tea, and get ready to go to our shop and I close the shop at 8:30 pm and go to bed at 9:00 pm. I can sleep well. I always listen to Buddhist channels on the radio, chanting pirith, and read the newspaper.

They use both Western and traditional medicine according to their symptoms. They take medicinal leaves and eat homemade food to maintain their health. They apply herbal hair oil, which they prepare themselves. P1 stated: I have some problem with my urinary bladder, for which I have had an operation. I am taking Western medicine. We always kept bottles of siddhalepa and asamodagam. Additionally, I used a medicine called jivaka. We used ath beheth for pain, bruises, lumps, and so on. We did not consult a doctor for every disease. I applied hair oil prepared by me. Now, although I arrange everything required for its preparation, I do not have enough time to grind the kalkaya. It is difficult for me to grind kalkaya as it takes three or four hours. I asked my elder daughter but she also does not have enough time to do it. Its preparation requires the grinding of many things, such as kithul, lime water with turmeric, kohomba kola, diya habarala, and so on. I often use this as hair oil. In addition, this oil is good for rashes, small wounds, burns, and so on. Rashes can be cured within five minutes. I learnt about this oil from a traditional local doctor. I stayed with a traditional local doctor part of the time. P3 mentioned: I have joint pain, especially in my legs, and applied oil or siddalepa and P4 described: I have kola kenda made from gotukola and iramusu once a week. I eat kola mallung such as kathurumurunga, gotukola, kesel muwa, jackfruit, breadfruit, and other vegetables.

\section{Discussion}

\subsection{Socioeconomic Background and QOL}

Education has been widely identified as a determinant of health outcomes as it shapes occupational opportunities and earning potential, which consequently affect living standards and healthcare (Hoi, Cuc, \& Lindholm, 2010; Adler \& Newman, 2002; Ross \& Wu, 1995). Sri Lanka implemented the free education system in 1944. Accordingly, the difference in literacy rate between the youth and the population over 65 is only $5-24 \%$ in Sri Lanka, while that in other South Asian countries was $25-49 \%$ in 2017. In this study, all respondents had obtained more than nine years of education, which was above average at that time. They are health conscious and have never had serious illnesses. The respondents often consume traditional herbal drinks and the choice between Western and traditional medicine was depending upon the severity of their symptoms. They are clear about the risk factors for NCD and how to prevent them. This was confirmed in the study by Liu, Zeng, Li \& Wang, 2013 and Chrusciel et al. 2018, in which the better QOL of well-educated respondents could be explained by their higher level of knowledge and pro-health awareness.

\subsection{Lifestyle Habits and QOL}

According to Conti (2016), the age at which a person receives an intervention affects the development of health behaviour. Early childhood is considered the most important developmental phase throughout the lifespan. Healthy early child development includes the physical, social-emotional, and language-cognitive domains of development, all of which strongly influence well-being, obesity/stunting, mental health, heart disease, competence in literacy and numeracy, criminality, and economic participation throughout life (Siddiqi, Irwin, \& Hertzman, 2007).

In this study, we revealed that all participants have been leading physically, psychologically, and spiritually balanced lives for a long time. They have never suffered from serious chronic illnesses and have enough physical strength to engage in their daily activities. In their childhood, all respondents walked several kilometres to school and back every day, and helped their parents with farming after school. Throughout their lives, they have consumed meals made from local produce, grown without too many chemical fertilisers. They emphasised the fact that fertilisers can damage health. As far as possible, they eat homemade meals because they are not sure of the ingredients used in readymade and store-bought foods. The prevalence of the risk of malnutrition is high among older persons in the community-dwelling setting. Age, hypertension, and alcohol consumption are significantly associated with malnutrition (Hewaratne, Moy, Abdullah, \& Dharmaratne, 2018a: 2018b). Older 
persons living in rural areas, those who brush once a day or less, and older persons with fewer natural teeth have an increased chance of reporting deterioration in oral health-related QOL (Dos Sautos, 2013). All the respondents in this study brush their teeth twice a day and manage to eat with natural teeth.

Depression (a lack of interest and pleasure in life) has been associated with the risk for under nutrition (Chen, Schilling, \& Lyder, 2001). Loneliness is associated with negative factors, including boredom and restlessness, ultimately leading to a decrease in food intake (Rathnayake, Wimalathunga, Weech, Jackson, \& Lovegrove, 2015; Higuchi 2018). The respondents in this study have regular family routines. None of them has suffered from a serious illness, whether physical or mental. In a previous study, certain subgroups of the elderly, that is, those with disabilities, functional limitations, perceived income inadequacy, minorities, and those living alone, were likely to report depressive symptoms (Malhotra, Chan, \& Ostbye, 2010). Moreover, the prevalence of depressive symptoms among the Sri Lankan elderly is higher than reported for most other Asian countries (Malhotra, Chan, \& Ostbye, 2010; Khaltar, et al., 2017). Our finding that none of the elderly had any sort of chronic illness complements the outcomes of previous studies. There was an association with alcohol in more than $10 \%$ of suicides and accidental deaths in Sri Lanka (Vadysinghe et al., 2018). All the respondents in this study have either never had alcohol or have it once or twice a year. Therefore, the lifestyles of the respondents in this study could serve as a model for the prevention of suicide and accidental death.

\subsection{Relationships and $Q O L$}

According to the census, in 2016, approximately $75 \%$ of Sri Lankan households were extended families; this was a $1.7 \%$ decline as compared to 2006 . All the participants in this study live with extended family in the same premises. At least one child stays with them, while others have moved nearby after marriage. However, they frequently visit, bringing the essentials with them. Social approval and self-esteem are necessary for a high QOL. However, social and personal roles change, many times in ways that are beyond our control. A study in China demonstrated that older adults living alone in rural areas face various pressures in life, including chronic diseases, 'empty nest syndrome', mental and physical disorders, serious psychological fatigue, and psychological problems (Liu, Zeng, Li, \& Wang, 2013). Older adults involved in relationships are more likely to have a high QOL than single respondents; loneliness in older adults is a very important factor resulting in a lowered QOL. Increase in physical activity significantly improves the QOL of older adults (Cwirlej-Sozanska, Sozanski, Wisniowska-Szurlej, \& Wilmowska-Pietruszynska, 2018). This study confirms that respondents living with family and moderate sense of distance in the home have never had serious illnesses, both mentally and physiologically. Moreover, in Sri Lanka, the community network is very tight both in public and private. Several committees, such as funeral-aid society and women's committees, have been organised in each grama niladhari (head of the grassroots level) area. All the participants in this study have been a member of the committee from time to time throughout their life. They maintain personal, family, and social relations and lead busy daily lives, which make them feel useful.

\subsection{Traditional Health Activities and QOL}

In Sri Lanka, traditional health behaviours are practised for health promotion and the prevention and treatment of illnesses. Traditional health practices, for example, balanced diets and hygiene, are integrated into daily life, and especially in the pre- and postnatal period (Higuchi, 2002). Sinhalese health culture includes a wide range of behaviours, and everything from folk dietetics to bathing and water boiling to the taking of birth control pills is influenced by hot/cold reasoning (Nichter, 1987). There are many kinds of herbs available in Sri Lanka, and these are used for everyday cooking (Jingfeng, 1991). The female respondents confirmed that they used foods according to hot and cold concepts during pregnancy and childbearing. It also concerned a nontoxic medication that normalises physiological functions disturbed by chronic stress through the correction of imbalances in the neuroendocrine and immune systems (Ven Murty, Ranjekar, Ramassamy, \& Deshpande, 2010). The respondents used to take herbal leaves from forests or mountainous areas, which are places where nontoxic leaves are found. The respondents combine the addition of certain kinds of leaves to a steam bath with chanting particular verses for recovering from illnesses, which helps them relax mentally.

\subsection{Religious Activities and $Q O L$}

Lower religious activity has been correlated with lower QOL and higher Beck Depression Inventory scores (Kao et al., 2003). Religiosity/spirituality and religious coping, in particular, influence changes in QOL over time. Religious coping relates to the use of religious resources (beliefs, practices, cognitive framework, and participation in religious services or volunteer work) in order to adapt to challenging circumstances (Stroppa, Fernando, Harold, \& Koening, 2018; Park, Holt Le, Christie, \& William CL, 2018).

Traditional religious ceremonies were found to lower the immune-stress related substance (IgA, 3 
methoxy-4hydroxy- phenylethyleneglycol) level in the saliva of Japanese females (Ishizu, et al., 2004).

The majority of the people in the area under study are Buddhists. They practiced religious activities during pre and post- natal and child bearing on the purpose of developing healthy child life. On the other hand, one of the villagers is selected as the Sunday school principal for children in the Buddhist temple. Villagers use the temple premises for their meetings. The respondents listen to religious radio programmes every morning and pray to gods to recover from illnesses.

\section{Conclusions}

Our study found that the QOL of senior citizens in Sri Lanka is related to factors such as education, psychological independence, sustaining daily life, engagement in social activities, satisfaction with children's support, and house sitting for their children.

Loneliness is associated with poor physical and mental health and an unhealthy lifestyle. Therefore, it is important to consider the effects of loneliness on physical and mental health and lifestyle in adults of all ages (Richard A. et al., 2017). In 2014, the British National Health Service recommended a five-step plan for achieving mental well-being and living a meaningful life: (1) connecting with community and family, (2) physical exercise, (3) lifelong learning, (4) giving to others, and (5) being mindful of the world around you. The present study revealed that QOL among senior citizens is influenced by a complex variety of demographic and sociocultural characteristics, education, life experiences, physical and mental health conditions, spiritual health practices, family, and social connectedness. Now, however, many of these factors are changing; the number of senior citizens has rapidly increased and the family structure has transformed from extended to nuclear. The findings of the Abecedarian Project regarding its participants at age 30 reinforce the importance of the first five years of life as a key stage during which cognitive skills that form the foundation for future success are acquired (Gampbell F, Conti, Heckman, \& Pinto, 2014). The findings of this study also suggest the need for a holistic approach right from childhood to develop self-control and physical, mental, and spiritual self-management so that a high QOL can be sustained throughout the lifespan. Further narrative research is required to bring out the individual experiences of senior citizens, which will help develop an effective strategy for sustaining the QOL of this population in Sri Lanka.

\section{Acknowledgements}

The authors acknowledge the senior citizens for their trust, valuable sharing, and contributions to the study.

\section{References}

Adler, N. E., \& Newman, K. (2002). Socioeconomic disparities in health: pathways and policies. Health Affairs, 21(2), 60-76. https://doi.org/10.1377/hlthaff.21.2.60

Campbell, F., Conti, G., Heckman, J. J., Moon, S. H., Pinto, R., Pungello, E., \& Pan, Y. (2014, March 28). Early childhood investments substantially boost adult health, National institutes of health public access. Science, 343(6178), 1478-85. https://doi.org/10.1126/science.1248429

Chen, C. C. H., Schilling, L. S., \& Lyder, C. H. (2001). A concept analysis of malutrition in the elderly. Journal of Advance Nursing, 36,131-142. https://doi.org/10.1046/j.1365-2648.2001.01950.x

Chruściel, P., Szczekala, K. M., Derewiecki, T., Jakubowska, K., Nalepa, D., Czekirda, M. E., ...Czarkowska, M. (2018). Differences in the quality of life dependent on family status of the elderly living in rural areas - a cross-sectional survey. Annals of Agricultural and Environmental Medicine, 25(3), 532-538. https://doi.org/10.26444/aaem/93501

Conti, G., Heckman, J., \& Pinto, R. (2016, October). The effects of two influential early childhood interventions on health and healthy behavior. Econ Journal of London, 126(596), F28-F65. https://doi.org/10.1111/ecoj.12420

Cwirlej-Sozanska, A. B., Sozanski, B., Wisniowska-Szurlej, A., \& Wilmowska-Pietruszynska, A. (2018). Quality of life and related factors among older people living in rural areas in south-eastern Poland. Annual Agricultural and Environmental Medicine, 25(3), 539-545. https://doi.org/10.26444/aaem/93847

Dos Santos, C. M., Martins, A. B., de Marchi, R. J., Hilgert, J. B., Hugo, F. N., \& Padilha, D. M. (2013). Assessing changes in oral health-related quality of life and its factors in community-dwelling older Brazilians. Gerodontology, 30, 176-186. https://doi.org/10.1111/j.1741-2358.2012.00656.x

Hewaratne, D. W. T. D., Moy, F. M., Abdullah, K. L., \& Dharmaratne, S. D. (2018a). Handgrip strength and its associated factors among community-dwelling elderly in Sri Lanka: a cross-sectional study. Asian Nursing 
Research, 12, 231-236. https://doi.org/10.1016/j.anr.2018.08.008

Hewaratne, D. W. T. D., Moy, F. M., Abdullah, K. L., \& Dharmaratne, S. D. (2018b). Prevalence of malnutrition and associated factors among community-dwelling older persons in Sri Lanka: a cross-sectional study. BMC Geriatrics, 18, 199. https://doi.org/10.1186/s12877-018-0892-2

Higuchi, M. (2002). Traditional health practices in Sri Lanka. Netherland: VU University Press.

Higuchi, M. (2018). Managing loneliness in the elderly and finding meaning in ageing. Journal of Comprehensive Nursing Research and Care, 125. Retrieved from https://gexinonline.com/uploads/articles/Article_JCNRC-125.pdf

Hoi, L.V., Chuc, N. T. K., \& Lindholm, L. (2010). Health-related quality of life, and its deteminants, among older people in rural Vietnam. BMC Public Health, 10, 549. https://doi.org/10.1186/1471-2458-10-549

Ishizu, H., Toyosato, T., Ota, M., Moriyama, K., Oshiro, K., Yokota, T., ... Yoshida, N. (2004). Correlative study between the subjective well-being and physical conditions of elderly people from the psychosomatic viewpoint in kudakajima island of Okinawa: Traditional holy paraying ceremony ("Matsuri") and Immune-, stress-related substances (IgA, MHPG) in saliva-, symposium/psychosomatic medicine towards health promotion. Japanese Journal of Psychosomatic Medicine, 44, 671-680.

Jingfeng, C. (1991). Nature's Way to Healthy Eating. Asiapac, Singapore: An Asiapac Publication.

Kao, T. W., Tsai, D. M., Wu, K. D., Shiah, C. J., Hsieh, B. S., \& Chen, W. Y. (2003, February). Impact of religious activity on depression and quality of life of chronic peritoneal dialysis patients in Taiwan. Journal of Formos Medical Association, 102(2), 127-30.

Khaltar, A., Priyandarshani, N. G. W., Delpitiya, N. Y., Jayashinghe, C., Jayasinghe, A., Arai, A., \& Tamashiro, H. (2017). Depression among older people in Sri Lanka: With special reference to ethnicity. Geriatric Gerontology. https://doi.org/10.1111/ggi.13090

Knudsen, E. I., Heckman, J. J., Cameron, J. L., \& Shonkoff, J. P. (2006, July 5). Economic, Neurobiological, and Behavioral Perspectives on Building American's Future Workforce. Retrieved from https://46y5eh11fhgw3ve3ytpwxt9r-wpengine.netdna-ssl.com/wp-content/uploads/2015/07/Economic_Neur obiological_Behavioral_Perspectives.pdf

Liu, N., Zeng, L., Li, Z., \& Wang, J. (2013). Health-related quality of life and long-term care needs among elderly individuals living alone: a cross-sectional study in rural areas of Shaanxi Province, China. BMC Pubic Health, 13, 313. https://doi.org/10.1186/1471-2458-13-313

Malhotra, R., Chan, A., \& Ostbye, T. (2010). Prevalence and correlates of clinically significant depressive symptoms among elderly people in Sri Lanka: finding from national survey. International Psychogeriatric, 22(2), 227-36. https://doi.org/10.1017/S1041610209990871

Miller, G., Vael, A. C., Hires, K. A., \& Eades, L. H. (2018). Child obesity: How engaging parents of children with elevated body mass index in positive dietary and lifestyle education in pediatric primary care improved parental role modeling practices within the home. J Comp Nurs Res Care, 3, 124.

Ministry of Health, Nutrition and Indigenous Medicine. (2014). Annual Health Bulletin.

Muenning, P., Robertson, D., Johnson, G., Campbell, F., Pungello, E. P., \& Neidell, M. (2011). The effect of an early education program in adult health: The Carolina Abecedarian Project Randomized controlled trial. American Journal of Public Health, 101(3), 512-516. https://doi.org/10.2105/AJPH.2010.200063

National Health Service. (n.d.). from https://www.nhs.uk/conditions/stress-anxiety-depression/improve-mental-wellbeing/five-steps-to-mental-w ellbeing,

Nicher, M. (1987). Cultural dimensions of hot, cold and sema in Sinhalese. Social Science and Medicine, 25(4), 377-87. https://doi.org/10.1016/0277-9536(87)90276-0

Park, C. L., Holt, C. L., Le, D., Christie, J., \& Williams, B. R. (2018). Positive and negative religious coping styles as prospective predictors of well-being in African Americans. Psycholog Relig Spiritual, 10(4), 318-326. https://doi.org/10.1037/rel0000124

Rathnayake, K. M., Wimalathunga, M. P. P. M., Weech, M., Jackson, K. G., \& Lovegrove, J. A. (2015). High prevalence of undernutrition and low dietary diversity in institutionalised elderly living in Sri Lanka. Public Health Nutrition, 18(15), 2874-2880. https://doi.org/10.1017/S1368980015000749

Richard, A., Rohrmann, S., Vandeleur, C. L., Schmid, M., Barth, J., \& Eichholzer, M. (2017, July 17). Loneliness 
is adversely associated with physical and mental health and lifestyle factors: Results from a Swiss national survey. PLOS one, 12(7), e0181442.

SEARO. (2018). Health SDG Profile: Sri Lanka. Retrieved from http://www.searo.who.int/entity/health_situation_trends/cp_srl.pdf?ua $=1$

Siddiqi, A., Irwin, L. G., \& Hertzman, C. (2007). Total environment assessment model for early child development, evidence report for the WHO's commission on the social determinants of health.

Stroppa, A., Colugnati, F. A., \& Koening, H. G. (2018). Alexander Moreira-Almeida, Religiosity, depression, and quality of life in bipolar disorder: a two-year prospective study. Brazilian Journal of Psychiatry, 40, 238-243. https://doi.org/10.1590/1516-4446-2017-2365

The Economist. (2014, November 24). Sri Lanka's healthcare challenges. Retrieved from http://country.eiu.com/article.aspx?articleid=1502512534\&Country=Sri\%20Lanka\&topic=Economy\&subto pic $=$ Forecast

UN Economic \& Social Affair. (2015). Report 2015 World population Ageing.

Vadysinghe, A. N., Senasinghe, P., Sivasubramanium, M., Jayasooriya, P., Premarathna, B. G., Rathnayake, R. M. I. S. D., \& Wickramasinghe, W. M. M. H. P. (2018). Unnatural Deaths of the Elderly Population of Sri Lanka: A Descriptive Analysis. American Journal of Forensic Medicince and Pathology, 39(2), 148-151.

Van der Vorst, A., Rixt Zijlstra, G. A., De Witte, N., Vogel, R. G. M., Schols, J. M. G. A., Kempen, G. I. J. M., \& Consortium D-Scope. (2017). Explaining discrepancies in self-reported quality of life in frail older people: a mixed-methods study. BMC Geriatrics, 17, 251. https://doi.org/10.1186/s12877-017-0641-y

Ven Murthy, M. R., Ranjekar, P. K., Ramassamy, C. (2010). Manasi Deshpande. Scientific basis for the use of Indian Ayurvedic Medicinal plants in the treatment of neurodegenerative disorders: 1. Ashwagandha, Central Nervous System Agents in Medical Chemistry, 10(3), 238-246. https://doi.org/10.2174/1871524911006030238

World Health Organization. (2018). Non-communicable Diseases (NCD) Country Profiles, Geneva, Switzerland.

\section{Appendix: Glossary}

\begin{tabular}{|c|c|}
\hline Achcharu & Sri Lankan pickles \\
\hline Angulimala & $\begin{array}{l}\text { Important figure in Buddhist literature, particularly within the Theravāda } \\
\text { tradition. Depicted as a ruthless brigand who completely transforms after a } \\
\text { conversion to Buddhism, he is seen as the example par excellence of the } \\
\text { redemptive power of the Buddha's teaching and the Buddha's skill as a teacher. } \\
\text { Angulimāla is seen by Buddhists as the "patron saint" of childbirth and is } \\
\text { associated with fertility in South and Southeast Asia }\end{array}$ \\
\hline
\end{tabular}

\begin{tabular}{ll}
\hline Asamodagan & Trachyspermum-roxburghianum \\
\hline Ath behet & Home remedies \\
\hline Bodhi pooja & Worship to Buddha, a ritual that take place at the Bo-tree of the temple \\
\hline Diya habarala & Arrow leaf pondweed/Monochoria hastata \\
\hline Gammudawa & $\begin{array}{l}\text { Gammaduwa is a whole-night ritual performed by a ritual healer/s with the } \\
\text { participation of the entire community for seeking the blessing and wellbeing } \\
\text { from the goddess pattini. The ritual takes place either at the deities' temple or a } \\
\text { hut that prepared at the village for this purpose. }\end{array}$ \\
\hline Gihipirith & Chanting pirith by general people \\
\hline Gotukola & Centella asiatica \\
\hline Grama niladhari & $\begin{array}{l}\text { Village officer, Sri Lankan public official appointed by the central government } \\
\text { to carry out administrative duties in a grama niladhari division, which is a } \\
\text { sub-unit of a divisional secretariat. }\end{array}$ \\
\hline Hulan iskothu & One kind of a hard biscuit \\
\hline Idul kata gema & A custom arrange to celebrate a child's first rice feeding at an auspicious time \\
\hline Iramusu & Hemidesmus indicus \\
\hline
\end{tabular}




\begin{tabular}{|c|c|}
\hline Jivaka & $\begin{array}{l}\text { King of the herbal medicine practitioners in the ancient Sri Lanka. Some herbal } \\
\text { medicine and clinics are named in Sri Lanka as Jivaka to show the importance } \\
\text { of that particular medicine or the clinic. }\end{array}$ \\
\hline Kalkaya & $\begin{array}{l}\text { Paste of herbal medicine etc. Buddharaja kalkaya, Chandra kalkaya, Desadun } \\
\text { kalkaya, Nawartne kalkaya, Sharkaradi kalkaya }\end{array}$ \\
\hline Kankun & Water morning-glory \\
\hline Kathurumurunga & Sesbania grandoflora \\
\hline Kappa mahatmayaa & Exorcist/ Ritual healer at the deities temple \\
\hline Kesel muwa & Banana flower \\
\hline Kiriammaa & Representing goddess pattini \\
\hline Kithul & Fish tail palm/Caryota urens \\
\hline Kohomba kola & Margosa/Azadirachta indica \\
\hline Kola-kenda & Soup made out of herbal leaves \\
\hline Koththamalli & $\begin{array}{l}\text { A flavoured tea beverage made by brewing coriander seeds and ginger. It is a } \\
\text { traditional Sri Lankan home remedy for curing the common cold and fever }\end{array}$ \\
\hline Lunu-dehi & lime preserved in salt \\
\hline Mallung & Chopped leaves mixed with grated coconut and red onions \\
\hline Mukunuwenna & Altenanthera sessilis \\
\hline Nadu haal & $\begin{array}{l}\text { A kind of traditional rice in Sri Lanka which is boiled before removing the } \\
\text { hard skin of un-milled rice }\end{array}$ \\
\hline Pattini amma & $\begin{array}{l}\text { It is believed to become a Buddha in a future birth, when she will be born as a } \\
\text { male. At the moment she is supposedly meditating, as is stated in Tamil } \\
\text { literature. }\end{array}$ \\
\hline Pirith & $\begin{array}{l}\text { Pirith is the Sinhala word for paritta (in Pali), which means protection. It } \\
\text { protects one from all directions. This is the recitation or chanting of the word } \\
\text { of the Buddha }\end{array}$ \\
\hline Polpala & Aerva lanata \\
\hline Rathu kekulu & One kind of traditional red rice in Sri Lanka \\
\hline Sambol & Prepare with grated coconut, chili, salt and lime juice. \\
\hline Siitala kaama & $\begin{array}{l}\text { It has an astringent property or obstruction to motion. Bitter, astringent, and } \\
\text { sweet substances are cold in quality. This quality (within comfortable limits) } \\
\text { encourage health by helping all tissues to last longer and is mainly found in } \\
\text { water. }\end{array}$ \\
\hline Siddhalepa & Very popular balm made by Sri Lanka Ayurveda drug company \\
\hline Sudu kekulu & A delectable white rice with a creamy taste and exquisite aroma \\
\hline Thambun hodhi & $\begin{array}{l}\text { Spicy gravy, Sri Lankans use very often when someone has an upset stomach, } \\
\text { and improve the digestion. The keep ingredient is tamarind, a kind of tropical } \\
\text { fruit that is often used in chutney recipes. It can be a little difficult to find in } \\
\text { your local supermarket, but nowadays you can find as a paste in your Asian } \\
\text { grocer. (https://lanka-journal.com/archives/543) }\end{array}$ \\
\hline Ushna kaama & $\begin{array}{l}\text { Excessive ushna quality in food is not helpful to the tissues. Ushna substances } \\
\text { like ginger and cinnamon have the power to cause perspiration. They abound } \\
\text { in heat. }\end{array}$ \\
\hline
\end{tabular}

\section{Copyrights}

Copyright for this article is retained by the author(s), with first publication rights granted to the journal.

This is an open-access article distributed under the terms and conditions of the Creative Commons Attribution license (http://creativecommons.org/licenses/by/4.0/). 